\title{
PeranPenerapan Model Pembelajaran Asuhan Bayi Balita dan Anak Pra SekolahTerintegrasi terhadap Motivasi dan Kompetensi Mahasiswa serta Kepuasan Pasien pada Praktik Klinik Kebidanan
}

\author{
Vera Renta $\mathrm{S}^{1}$, Deni K Sunjaya ${ }^{2}$, Meita Dhamayanti ${ }^{3}$ Farid Husin $^{4}$, Nanan Sekarwarna ${ }^{5}$, Rovina Ruslami ${ }^{6}$, Ishak \\ Abdulhak $^{7}$ \\ ${ }^{1}$ Mahasiswa Program Studi Kebidanan Fakultas Kedokteran Universitas Padjadjaran Bandung \\ ${ }^{2}$ Departemen Ilmu Kesehatan Masyarakat Universitas Padjadjaran Bandung \\ ${ }^{3}$ Departemen Ilmu Kesehatan Anak Universitas Padjadjaran Bandung \\ ${ }^{4}$ Departemen Epidemiologi dan Biostatistika Fakultas Kedokteran Universitas Padjadjaran \\ ${ }^{5}$ Departemen Ilmu Kesehatan Anak Universitas Padjadjaran Bandung \\ ${ }^{6}$ DepartemenFarmakologiUniversitas Padjadjaran Bandung \\ ${ }^{7}$ Program StudiPengembanganKurikulumSekolahPascaSarjanaUniversitas Pendidikan Indonesia
}

\begin{abstract}
Abstrak
Bidan yang kompeten tidak hanya mampu dalam pengetahuan, sikap dan keterampilan, namun mampu memberikan asuhan yang berpusat terhadap pemenuhan kebutuhan masyarakat.Hasil uji kompetensi tahun 2013 yang dilakukan terhadap mahasiswa program studi DIII kebidanan didapatkan hanya $53 \%$ yang lulus. Peningkatan kualitas bidan harus didukung dengan peningkatan kualitas pendidikan. Model pembelajaran terintegrasi diperlukan guna meningkatkan kualitas kompetensi bidan dan dapat memenuhi kebutuhan masyarakat. Penelitian ini bertujuanu ntuk menganalisis peran penerapan model pembelajaran asuhan bayi balita dan anak rasekolah terintegrasi terhadap motivasi dan kompetensi mahasiswa serta kepuasan pasien dalam praktik klinik kebidanan.Rancangan penelitian kuantitatif dengan pendekatan analitik menggunakan quasi experiment dengan pre-post test design.Populasi penelitian adalah mahasiswa DIII Kebidanan Universitas Sebelas Maret (UNS)Surakarta semester IV dan ibu yang memiliki bayi balita dan anak pra sekolah yang mendapatkan pelayanan dari mahasiswa DIII Kebidanan UNS Surakarta semester IV. Sampel penelitian adalah total populasi dengan jumlah 37 mahasiswa UNS semester IV dan 37 pasien. Penelitian dilakukan di Prodi D III Kebidanan UNS Surakarta pada bulanApril - Juli 2015.Variabelpenelitianadalahmodel pembelajaran, motivasi, kompetensi dan kepuasan. Analisis data menggunakan uji wilcoxon, chi square, spearman rank, dan regresi logistik. Hasil penelitian menunjukkan terdapat efek penerapan model pembelajaran asuhan bayi balita dan anak pra sekolah terintegrasi terhadap motivasi mahasiswa (52 (43-84) vs 76 (72-92), $p<0,05)$ dan kompetensi mahasiswa (0 vs 8). Terdapat peran kompetensi mahasiswa setelah penerapan model pembelajaran asuhan bayi balita dan anak pra sekolah terintegrasi terhadap kepuasan pasien, $p<$ 0,05 . Penerapan asuhan bayi balita dan anak prasekolah terintegrasi dapat menjadi alternatif dalam pembelajaran di Institusi Kebidanan. Model pembelajaran asuhan bayi balita dan anak prasekolah terintegrasi dapat meningkatkan motivasi dan kompetensi mahasiswa pada praktik klinik kebidanan. Kompetensi mahasiswa berperan terhadap kepuasan pasien pada praktik klinik kebidanan.
\end{abstract}

Kata kunci : Model Pembelajaran Terintegrasi, Motivasi, Kompetensi, KepuasandanKebidanan 


\begin{abstract}
A competence midwife was able to give a health service focused on fulfilling public demands. The test competence among the midwife student of diploma three programme indicated that only $53 \%$ could past the test. A Process of midwife programme education was also influenced by a learning model. A integrated learning model was needed in order to improve the widwifes competence and to fulfil public demands as well. The objectives of the reasearch was to analyze the role of application integrated learning model of infant and pre school agebetween motivation and competences of students with patients satisfaction in midwife practice clinic.The research was a quantitative study with analytical approach used the quasi experiment with pre post test design. The population was 37 midwife diploma students in 4 th semester of SebelasMaret University Surakarta and that gave health services to 37 infant and pre school age mothers. The samples were total population samples. The research was located in midwife diploma programme of SebelasMaret University Surakarta on April to July 2015. The research variablesaremodelof learning, motivation, competenceandsatisfaction.The data were analyzed by using Wilcoxon, Rank Spearman, Chi Square and logistic binary regression.The result of the research showed that the effect ofthe application oflearningmodel of infant and pre school age on the motivation ofthe students(52 (43-84) vs.76(72-92) andcompetence ofstudents(0 vs8),p<0.05. Students competenceare ruledto mothers satisfaction inmidwife clinic practice afterapplication of the integrated learning model of infant and pre school age,

$\mathrm{p}<0.05$. Integrated learning model of infant and pre school age canbe an alternativelearning.Integrated learning model of infant and pre school age can increasestudentmotivationandcompetenceinclinical practicemidwife. Students competence are ruled to mothers satisfaction in midwife clinic practice.
\end{abstract}

Keywords: Integrated learning model, motivation, competence, satisfaction and midwife

\section{Pendahuluan}

Bidan merupakan salah satu tenaga medis yang dapat berperan dalam upayamewujudkan pencapaian derajat kesehatan masyarakat. ${ }^{1-}$ ${ }^{3}$ Peningkatan kualitas bidan harus didukung dengan peningkatan kualitas pendidikan., 4 , ${ }^{5}$ Institusi pendidikan merupakan lembaga yang memberikan jasa pelayanan dalam pendidikan., Profesi bidan yang dihasilkan oleh institusi pendidikan dapat mencapai hasil yang diharapkan bila mengikuti perkembangan globalisasi dan menyesuaikan dengan kebutuhan masyarakat. ${ }^{1,4}$ Tujuan pendidikan profesi bidan pada awalnya adalah untuk memenuhi kebutuhan dan meningkatkan derajat kesehatan masyarakat. Namun, pendidikan profesi bidan saat ini terjadi peningkatan jumlah institusipendidikan kebidanan yang pesat. ${ }^{1}, 4,{ }^{5}$ Jumlah institusi pendidikan Diploma III (DIII) kebidanan yang diselenggarakan oleh pemerintah maupun swasta saat ini menghasilkan ribuan lulusan bidan setiap tahunnya. Banyaknya lulusan pendidikan kebidanan tersebut tidak diimbangi dengan peningkatan mutu. ${ }^{1,5}$ Mutu lulusan kebidanan mempengaruhi kualitas lulusan dan kualitas pelayanan kesehatan. ${ }^{1,5,7}$
Kualitas lulusan tidak diimbangi dengan peningkatan jumlah institusipendidikan, tercermin dari hasil uji kompetensi bagi mahasiswa Program DIII Kebidanan. Hasil uji kompetensi menunjukkan kelulusan mahasiswa program D III Kebidanan Tahun 2013 sebesar 53.5\% dengan batas nilai kelulusan $40,41 .{ }^{8}$ Data berdasarkan laporan Kementerian Kesehatan tentang kualitas pelayanan kesehatan ibu di Indonesia Tahun 2012 menunjukkan bahwa kompetensi lulusan bidan masih di bawah standar. ${ }^{9}$ Berdasarkan hal tersebut diperlukan adanya strategi dalam pendidikan untuk meningkatkan kualitas lulusan. ${ }^{1,5,8}$

Kompetensi yang dicapai oleh mahasiswa dapat dipengaruhi oleh beberapa faktor, baik yang berasal dari diri siswa (faktor internal) maupun dari luar siswa (faktor eksternal). ${ }^{10}$ Faktor internal diantaranya adalah minat, bakat, motivasi, tingkat intelegensi, sedangkan faktor eksternal diantaranya adalah metode pembelajaran dan lingkungan. ${ }^{10}$ Hasil penelitian tersebut juga didukung oleh penelitian Irianti (2014) yang menyebutkan bahwa sebesar 64\% dari mahasiswa kebidanan memiliki motivasi yang rendah dalam belajar. ${ }^{11}$ 
Bidan yang kompeten tidak hanya mampu dalam pengetahuan, sikap dan keterampilan, namun mampu memberikan asuhan., 3 ${ }^{4}$ Masyarakat setiap tahunnya mengalami perkembangan baik dari segi pendidikan, pengetahuan, status ekonomi dan budaya. ${ }^{4,5}$, ${ }^{12}$ Perkembangan yang dialami masyarakat berdampak pada perubahan pola kesehatan dan kebutuhan terhadap jenis dan kualitas pelayanan kesehatan. Masyarakat tentu menuntut institusi kebidanan agar meningkatkan kualitas lulusan yang dapat memenuhi kebutuhan masyarakat., ${ }^{4,}$

Survei yang dilakukanmahasiswakebidanan UNPAD dibeberapa puskesmas di provinsi yaitu Jawa Timur, Jawa Tengah, Jawa Barat, DKI Jakarta dan Padang terhadap 604 wanita. Hasil survei menunjukkan $98 \%$ responden menginginkan bidan yang tidak hanya mampu menyelesaikan masalah mereka tetapi juga diperlukan bidan yang mampu berkomunikasi, sabar dan ramah. ${ }^{11}$ Berdasarkan hal tersebut seorang bidan dalam memberikan asuhan kebidanan memerlukan kemampuan pengintegrasian antara soft skill, pengetahuan dan keterampilan guna memenuhi kebutuhan masyarakat. ${ }^{11,13}$

Telahdilakukan survei pendahuluan pada workshop asuhan kebidanan terintegrasi. Workshop diikuti oleh dosen dan pembimbing klinik yang berjumlah 115 orang di Surakarta. Hasil survei menunjukkan permasalahan yang dialami pembimbing klinik di lahan praktik yaitu mahasiswa kurang aktif dan kurang komunikatif. Harapan pembimbing klinik terhadap mahasiswa agar memberikan asuhan terhadap pasien dengan pandai, ramah, terampil, komunikatif, sopan dan disiplin.99\% respondenmenyatakan bahwa asuhan kebidanan terintegrasi perlu dilakukanguna meningkatkan kualitas lulusan.

Tenaga bidan yang kompeten perlu dipersiapkan melalui proses pembelajaran. Peserta didik perlu diberikan pendekatan melalui model pembelajaran yang baik guna membantu mengembangkanmotivasidankompetensi. ${ }^{6,14}$ Saat ini pendidikan kebidanan masih menggunakan model pembelajaran terpisah-pisah dalam proses pembelajaran. $^{2}$ Model pembelajarantersebut mengakibatkan mahasiswa tidak aktif, tidak berpirikir kritis, dan siswa tidak diberikanpendekatan pemenuhan kebutuhan manusiasecara holistik. ${ }^{12,}{ }^{15}$ Pendekatan dengan integrasi membantu peserta didik agar memahami lebih baik danmemudahkanbelajarkasus klinis pada praktikklinikkebidanan. ${ }^{14,} \quad{ }^{15}$ Metode alternatif ini merupakan suatu pendekatan yang baik dan bermanfaat bagi peserta didik disuatu institusi. $^{12,14-17}$

Penelitian model pembelajaran terintegrasi telah dilakukan sebelumnya oleh Irianti (2014) di pendidikan D III kebidanan dengan pembelajaran di kelas. Hasil penelitian menunjukkan terdapat peningkatan kompetensi mahasiswa. ${ }^{11}$ Gurtoo,dkk (2013) melakukanpenelitian dengan mengintegrasikan pelajaran humaniora ke dalam kurikulum kedokteran di India. Hasil menunjukkan bahwa 73\% dari mahasiswa dilaporkan merasakan perubahan perilaku yang positif terhadap pasien dan $82 \%$ mahasiswa lebih termotivasi untuk belajar. ${ }^{18}$ Perlu dilakukan penelitianpenerapan model asuhan kebidanan terintegrasi di praktik klinikkebidanan. Peserta didik dapat memberikan asuhan dengan memahami kebutuhan emosional dan psikologis pasien secaralangsung pada pembelajaran klinik dengan menerapkanpengetahuan dan keterampilan yang telahdidapatkan sebelumnya. ${ }^{18,19}$

Model pembelajaran terintegrasi dapatditerapkan pada institusi dimana peran pendidik dalam pembelajaran berfungsi sebagai fasilitator. Peserta didik dapat berperan secara aktif di dalam proses pembelajaran. ${ }^{12,14,20}$ Model asuhan bayi balita dan pra sekolah terintegrasi diharapkan dapat meningkatkan motivasi dan kompetensi pada mahasiswa DIII Kebidanan UNS Surakartaserta kepuasan pasien di praktek klinik kebidanan.Pada saat ini belum diketahui model pembelajaran asuhan bayi, balita dan anak pra sekolah yangdapat berperan dalam meningkatkan motivasi dan kompetensi mahasiswa serta kepuasan pasien di praktik klinik kebidanan.

Berdasarkan latar belakang diatas penting untuk dilakukan penelitian mengenai "Peran penerapan model pembelajaran asuhan bayi balita dan anak pra sekolah terintegrasi terhadap motivasi dan kompetensi mahasiswa serta kepuasan pasien pada praktik klinik kebidanan".

\section{Metode \\ Populasi dan Sampel}

Populasi dalam penelitian ini adalah mahasiswa DIII Kebidanan Universitas Sebelas Maret (UNS) Surakarta semester IV Tahun Ajaran 2014/2015. Ibu yang memiliki bayi balita 
dan anak pra sekolah yang mendapatkan pelayanan asuhan bayi balita dari mahasiswa DIII Kebidanan UNSSurakarta semester IV Tahun Ajaran 2014/2015.Sampel dalam penelitian inimenggunakan total populasiyaitusebanyak 41 mahasiswadan 41 ibu yang memilikibayibalitadananakprasekolah.

\section{Kriteria inklusi dan eksklusi}

Kriteria inklusi dan eksklusi dalam penelitian ini yaitu :

1. Mahasiswa :

Kriteria inklusi dalam penelitian ini adalah :

a. Mahasiswa semester IV di DIII Kebidanan UNS Surakarta

b. Mahasiswa bersedia menjadi responden penelitian

c. Mahasiswa telah lulus seluruh mata kuliah semester sebelumnya

Kriteria eksklusi dalam penelitian ini adalah :

a. Mahasiswa yang tidak mengikuti tes selama penelitian

b. Mahasiswa yang tidak hadir lebih dari 20 $\%$ selama penguatan asuhan bayi balitadiberikan.

2. Ibu dari bayi, balita dan anak pra sekolah

Kriteria inklusi dalam penelitian ini adalah :

a. Ibu yang bersedia menjadi responden

b. Ibu yang dapat membaca dan menulis

c. Ibu yang memiliki bayi, balita dan anak pra sekolah

d. Ibu yang anaknya mendapatkan pelayanan asuhan bayi, balita oleh mahasiswa DIII Kebidanan UNS semester IV

Kriteria eksklusi dalam penelitian ini adalah :

a. Bayi, balita dan anak pra sekolah yang sedang dalam ruang perawatan inap

\section{Rancangan Penelitian}

Rancangan penelitian ini yaitu kuantitatif dengan pendekatan analitik menggunakan rancangan quasi experiment dengan pre-post test design. ${ }^{21}$ Penelitian ini dilakukan pada satu kelompok yang diberikan perlakuan dengan dua kali pengukuran tes pada motivasi dan kompetensi mahasiswa. Tes pertama dilakukan sebelum diberikan intervensi (pre-test) dan tes kedua dilakukan setelah diberikan intervensi (post-test) dengan menggunakan kuesioner yang sama. Kepuasan pasien dinilai setelah mahasiswa memberikan asuhan bayi balita dan anak pra sekolah kepada pasien setelah mahasiwa memperoleh intervensi.Pada penelitian ini, kelompok diberikan intervensi dalam bentuk model pembelajaran asuhan bayi balita dan pra sekolah terintegrasi.

\section{Hasil Ukur}

Hasil utama yang diukur dalam penelitian ini adalah perbedaan motivasi dan kompetensi mahasiswa sebelum dan sesudah mendapatkan model pembelajaran asuhan bayi balita dan anak pra sekolah terintegrasi praktik klinik kebidanan. Hasil utama lainnya adalah peran kompetensi mahasiswa

(pengetahuan,sikapdanketerampilan)terhadap kepuasan pasien dalam praktik klinik kebidanan.

Hasil sampingan penelitian yaitu perbedaan sebelum dan sesudah mendapatkan model pembelajaran asuhan bayi balita dan anak pra sekolah terintegrasi sehubungan dengan motivasi mahasiswa yang terdiri dari perhatian (attention), relevansi(relevance), kepercayaan (confidence), dan kepuasan (satisfaction), kompetensi yang terdiri dari pengetahuan sikap dan keterampilan, serta kepuasan pasien terhadap layanan yang diberikan oleh mahasiswa terdiri darikepuasan umum, kualitas teknik, kemampuan interpersonal, komunikasi, dan waktu yang digunakan.

\section{Alur Penelitian}

Prosedur penelitian yang dilakukan adalah :

a. Menyelenggarakan workshop model pembelajaran asuhan kebidanan terintegrasi dengan mengundang dosen dan pembimbing klinik (CI) yang menilai mahasiswa dilahan praktik untuk menyamakan persepsi

b. Membuat modul praktik asuhan bayi, balita dan anak pra sekolah terintegrasi yang berisi petunjuk belajar, daftar tilik dan langkah kerja dalam mencapai kompetensi asuhan bayi, balita dan anak pra sekolah.

c. Membuat instrumen penelitian mengenai kompetensi, motivasi dan kepuasan.

d. Meminta perizinan persetujuan komite etik dan perizinan di tempat penelitian dilakukan.

e. Mahasiswa sebelum diberikan perlakuan, terlebih dahulu diberikan penjelasan mengenai proses penelitian dan perlakuan yang akan diterima oleh mahasiswa, apabila mahasiswa bersedia maka dapat menandatangani lembar persetujuan.

f. Peneliti kemudian melakukan penilaian terhadap motivasi dan kompetensi mahasiswa padapraktik klinik kebidanan. 
g. Setelah itu, intervensi model pembelajaran asuhan bayi balita dan anak pra sekolah terintegrasi diberikan kepadamahasiswa.

h. Pada pelaksanaan proses dilakukan intervensi selama 4 minggu.

i. Tahap terakhir peneliti melakukan evaluasi penilaian dengan menggunakan instrumen yang sama dengan sebelum diberikan intervensi. Evaluasi penilaian dilakukanterhadapmotivasi dan kompetensi mahasiswa padapraktik klinik.Penilaian sikap dan keterampilan mahasiswa dilakukan pengukuran saat mahasiswa melakukan asuhan langsung terhadap pasien.Penilaian aspek sikap dan keterampilan dinilai langsungoleh CI.Terakhir dilakukan penilaian terhadap kepuasan pasien setelah pasien mendapatkan pelayanan yang diberikan oleh mahasiswa.

\section{Instrumen Penelitian}

Penelitian ini menggunakan instrumen guna mengukur motivasi, kompetensi (pengetahuan, sikap dan keterampilan), dan kepuasan. Instrumen motivasi menggunakan kuesioner yang dibuat berdasarkan indikator teori John Keller dan studi literatur yang kemudian dilakukan kajian. Instrumen untuk mengukur motivasi menggunakan indikator ARCS yaitu perhatian (attention), relevansi (relevance), kepercayaan (confidence), dan kepuasan (satisfaction). ${ }^{22-24}$ Kuesioner diadopsi dari penelitian sebelumnya dan dikumpulkan dengan menggunakan skala likert.Instrumen pengetahuan dibuat dengan soal pilihan ganda berbasis kasus. ${ }^{11}$ Instrumen penilaian sikap dan keterampilan menggunakan daftar tilik yang telah dibuat dengan indikator yang harus dicapai oleh mahasiswa. Instrumen kepuasan menggunakan skala pengukuran kuesioner kepuasan pasien yang dibuat berdasarkan kajian literaturpatient satisfaction questioner (PSQ). ${ }^{25-27}$

\section{Rancangan Analisis}

Data dilakukan terlebih dahulu uji normalitas untuk mengetahui apakah data berdistribusi normal atau tidak. Analisis univariat untuk melihat distribusi frekuensi.Analisis bivariat, uji Wilcoxon (data tidak berdistribusi normal) dilakukan untuk menganalisis perbedaan nilai pre test dan post test. ${ }^{28} \mathrm{Uji}$ chi square dilakukan untuk menganalisis uji beda antara ipk dan kompetensi mahasiswa.Uji korelasi spearman dilakukan untuk menganalisis korelasi motivasi dengan kompetensi mahasiswa. Analisis multivariabel dilakukan untuk menganalisa peran kompetensi (pengetahuan, sikapdanketerampilan) mahasiswa setelah penerapan model pembelajaran asuhan bayi balita dan anak pra sekolah terintegrasi terhadap kepuasan pasien pada praktek klinik kebidanan menggunakan uji regresi logistik. ${ }^{28}$

\section{Hasil}

Hasilpenelitianinimeliputianalisisdeskriptif (univariat) yang menggambarkan data karakteristikresponden.Karakteristikrespondendis iniberupaindeksprestasidariresponden.Responden dalampenelitianiniberjumlah 37 mahasiswa.

\section{Tabel1.1 KarakteristikSubyekPenelitian}

\begin{tabular}{lll}
\hline Karakteristik & N & \% \\
\hline IndeksPrestasi & & \\
Kurang & 4 & 10.81 \\
Memuaskan & 8 & 21.62 \\
SangatMemuaskan & 22 & 59.46 \\
DenganPujian & 3 & 8.11 \\
\hline Total & 37 & 100 \\
\hline Motivasi Pre & & \\
$\quad$ Median & 52 & \\
$\quad$ Min - Maks & $43-84$ & \\
\hline
\end{tabular}

Tabel 1.1 menunjukkanbahwa $59.46 \%$ mahasiswa DIII UNS Surakarta semester IV memilikiindeksprestasisangatmemuaskan> 3.00 3.50. Motivasi menunjukkan bahwa terdapat mahasiswa yang memiliki motivasi di bawah median dalam praktik klinik kebidanan. Karakterisktikmahasiswatersebutselanjutnyadian alisislebihlanjutuntukmelihathasilpenelitian yang diperolehbenar - benardipengaruhiolehintervensi yang telahdiberikan.

Analisis perbedaan pre tes dan pos tes bertujuan untuk melihat perbedaan dan peningkatan antara nilai pre tes dan pos tes yang disebabkan oleh model pembelajaran asuhan bayi balita dan anak pra sekolah terintegrasi. Aspek yang dinilai dalam penelitian ini yaitu perbedaan dan peningkatan motivasi. Peningkatan nilai motivasi dapat dilihat pada tabel 1.2 berikut :

Tabel 1.2Efek penerapan model pembelajaran asuhan bayi, balita dan anak pra sekolah terintegrasi terhadap motivasi mahasiswa pada praktik klinik kebidanan 


\begin{tabular}{lrccc}
\hline $\begin{array}{l}\text { Variab } \\
\text { el }\end{array}$ & Pre test & $\begin{array}{l}\text { Post } \\
\text { test }\end{array}$ & P & $\begin{array}{c}\% \\
\text { Pening } \\
\text { katan }\end{array}$ \\
\hline $\begin{array}{l}\text { Motiva } \\
\text { si }\end{array}$ & 52 & 76 & $<0.00$ & 40.48 \\
Median & $43-$ & $72-92$ & $1 *$ & $\%$. \\
Min - 84 & & & & \\
Maks & & & & \\
\hline Keterangan : *Uji Wilcoxon & & & \\
\hline
\end{tabular}

Tabel 1.2 diatas menunjukkan bahwa variabel motivasi mengalami peningkatan nilai median sesudah diberikan model pembelajaran asuhan bayi balita dan anak pra sekolah terintegrasi, dengan beda peningkatan yang bermakna $(\mathrm{p}<0.001)$.

Aspek yang dinilai dalam penelitian ini yaitu perbedaan dan peningkatan pengetahuan, sikap dan keterampilan. Analisis nilai pre tes dan pos tes dilakukan menggunakan uji Wilcoxon uji alternatif yang digunakan karena data tidak berdistribusi normal. Peningkatan nilai kompetensi (pengetahuan, sikap dan keterampilan) dapat dilihat pada tabel 1.3:

Tabel 1.3 Efek penerapan model pembelajaran asuhan bayi, balita dan anak pra sekolah terintegrasi terhadap kompetensi mahasiswa pada praktik klinik kebidanan

\begin{tabular}{lcccc}
\hline \multicolumn{1}{c}{ Aspek } & Pre test & Post test & $\begin{array}{c}\boldsymbol{p} \\
\begin{array}{c}\% \\
\text { Penin } \\
\text { gkata } \\
\text { n }\end{array}\end{array}$ \\
\hline $\begin{array}{l}\text { Kompetensi } \\
\text { TidakKompe } \\
\text { ten }\end{array}$ & $\begin{array}{c}37 \\
(100 \%)\end{array}$ & $29(78 \%)$ & $\begin{array}{l}21,62 \\
\%\end{array}$ \\
Kompeten & 0 & $(0)$ & $8(22 \%)$ & \\
\hline
\end{tabular}

Tabel 1.3 diatas menunjukkan bahwa semua kompetensimahasiswa mengalami peningkatan antara sebelum dan sesudah diberikan model pembelajaran asuhan bayi balita dan anak pra sekolah terintegrasi.

Karakteristik mahasiswa dianggap sebagai perancu terhadap peningkatan kompetensi mahasiswa adalah indeks prestasi. Peningkatan kompetensi mahasiswa dianalisis secara bivariat terhadap indeks prestasi antar mahasiswa. Analisis bivariat kategorik Uji Fisher exact sebagai alternatif dilakukan untuk melihat indeks prestasi bukan merupakan sebagai faktor yang menyebabkan peningkatan kompetensi mahasiswa dalam penelitian ini. Hasil analisis tersebut terdapat pada tabel1.4 berikut :

Tabel 1.4. Hubungan indeks prestasi (perancu) terhadap kompetensi

\begin{tabular}{|c|c|c|c|}
\hline \multirow{2}{*}{$\begin{array}{c}\text { IndeksPresta } \\
\text { si }\end{array}$} & \multicolumn{2}{|c|}{ Kompetensi } & \multirow{2}{*}{$\begin{array}{l}\text { Nilai } \\
\rho\end{array}$} \\
\hline & $\begin{array}{c}\text { Kompete } \\
\text { n }\end{array}$ & $\begin{array}{c}\text { TidakKo } \\
\text { mpeten }\end{array}$ & \\
\hline $\begin{array}{l}\text { KurangdanMe } \\
\text { muaskan }\end{array}$ & $1(8.3 \%)$ & $11(91.7 \%$ & $\begin{array}{l}0,23 \\
2\end{array}$ \\
\hline $\begin{array}{l}\text { SangatMemua } \\
\text { skan } \\
\text { danDenganPuj } \\
\text { ian }\end{array}$ & $7(28 \%)$ & $\begin{array}{c}18 \\
(72 \%)\end{array}$ & \\
\hline
\end{tabular}

Tabel 1.4 menunjukkan bahwa variabel indeks prestasi tidak memengaruhi peningkatan kompetensi mahasiswa (nilai $\mathrm{p}>0.05$ ) sehingga indeks prestasi dihilangkan sebagai perancu.

Analisis korelasi rank spearman dilakukan untuk mengetahui korelasi antara motivasi dengan kompetensi mahasiswa. Korelasi antara motivasi dengan kompetensi mahasiswa dalam asuhan bayi balita dan anak pra sekolah terintegrasi dijabarkan pada tabel 1.5 dibawah ini:

Tabel 1.5 Korelasi antara motivasi dengan kompetensi asuhan bayi balitadan anak pra sekolah terintegrasi pada praktik klinik kebidanan

\begin{tabular}{cccc}
\hline \multirow{2}{*}{ Variabel } & \multicolumn{3}{c}{ KompetensiMahasiswa } \\
\cline { 2 - 4 } & Koefisienkorelasi & p value & N \\
\hline Motivasi & 0.159 & 0.348 & 37 \\
\hline Keterangan : & Uji korelasi spearman & &
\end{tabular}

Berdasarkan tabel 1.5 menunjukkan bahwa tidak terdapat korelasi antara motivasi dengan kompetensi mahasiswa, dengan nilai $\mathrm{p}>0.05$.

Analisis regresi logistik berganda dilakukan dengan metode backward dalam penelitian ini. Peran model pembelajaran terintegrasi dalam kompetensi (pengetahuan,sikap dan keterampilan) mahasiswa serta kepuasan pasien dijabarkan pada tabel 1.6 berikut: 
Tabel 1.6 Peran model pembelajaran asuhan bayi balita dan anak prasekolah terintegrasi terhadap kompetensi (pengetahuan, sikap dan keterampilan) mahasiswa serta kepuasan pasien padapraktikklinik kebidanan

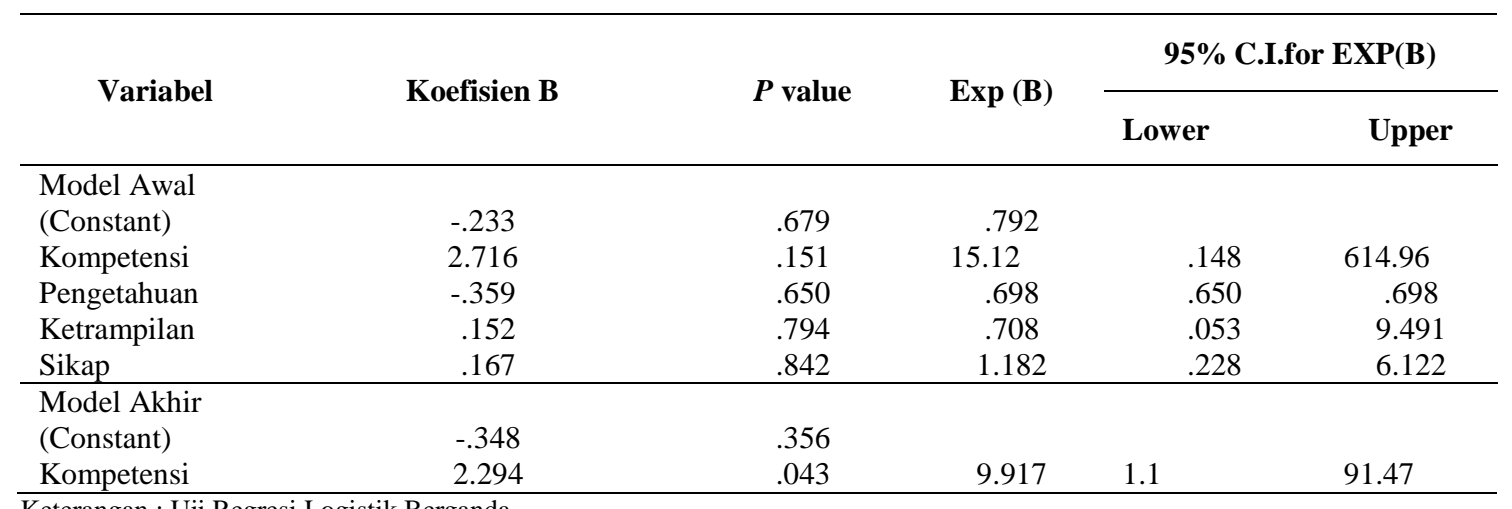

Keterangan : Uji Regresi Logistik Berganda

Tabel 1.6 diatas menunjukkan hasil bahwa dari model awal yaitu variabelkompetensi, pengetahuan, keterampilan dan sikap mahasiswa yang memengaruhi kepuasan pasien adalah nilai kompetensi mahasiswa, dengan nilai $\mathrm{p}<0.05$. Nilai pos kompetensi mahasiswa berperan terhadap kepuasan pasien pada praktik klinik kebidanan. Pengaruh yang ditimbulkan oleh nilai kompetensi terhadap kepuasan pasien pada praktik klinik kebidanan sebesar 9,92 kali dibandingkan dengan mahasiswa yang tidak kompeten.Hasil OR sebesar 9,92 kali, akan tetapi hasil menunjukkan rentang nilai interval kepercayaan yang lebar.

\section{Diskusi}

Model pembelajaran asuhan bayi balita dan anak pra sekolah terintegrasi diharapkan dapat memenuhi kebutuhan secara holistik. Pendekatan dengan integrasi dapat membantu peserta didik memahami lebih baik, lebih aktif dan dapat berkorelasi dengan kasus klinis pada situasi nyata. ${ }^{14-16,20,29,30}$ Keberhasilan model pembelajaran terintegrasi dalam proses pembelajaran dapat dinilai dari motivasidan kompetensi mahasiswa. ${ }^{7,31}$

Hasil penelitian menunjukkan peningkatan nilai pada aspek motivasi antara sebelum dan setelah diberikan model pembelajaran terintegrasiyang bermakna, $(\mathrm{p}<0.001$ pada tabel 1.2). Model pembelajaran asuhan bayi balita dan anak pra sekolah terintegrasi dapat meningkatkan motivasi sebesar $40.48 \%$ dalam penelitian ini.

Hasil pengumpulan data pos tes (setelah diberikan intervensi) menunjukkan peningkatan nilai motivasi dibandingkan sebelum diberikan intervensi. Terdapat perbedaan motivasimahasiswayang bermakna secara statistik antara sebelum dan sesudah intervensip< 0.001). Hasil tersebut menunjukkan bahwa model pembelajaran terintegrasi mampu meningkatkan motivasi mahasiswa dalam praktik klinik kebidanan.

Berdasarkan penelitian yang dilakukan oleh Adnan, dkk (2012) terdapat beberapacara yang dapat dilakukan untuk meningkatkan motivasi dalampembelajaran. Cara yang dapat dilakukan yaitu dengan model pembelajaran yang bervariasi, menggunakan media pembelajaran, kegiatan praktikum, menghubungkan materi pembelajaran, siswa mengetahui materi yang harus dipelajari, dan contoh kasus yang memudahkan siswa untuk memahami materi pembelajaran. ${ }^{22,}{ }^{23}$ Model pembelajaran asuhan bayi balita dan anak pra sekolah terintegrasi dalam penelitian ini dapat meningkatkan motivasi mahasiswa. Sesuai dengan hasil penelitian yang dilakukan oleh Adnan, dkk (2012) bahwa model pembelajaran yang didalam prosesnya menggunakan media, praktikum, kasus dan menghubungkan antar materi pelajaran dapat meningkatkan motivasi mahasiswa. Model pembelajaran asuhan bayi balita dan anak pra sekolah terintegrasi belum optimal dalam meningkatkan motivasi. ${ }^{22} \mathrm{Hal}$ tersebut dapat dikarenakan bahwa terdapat faktor - faktor yang dapat memengaruhi motivasi mahasiswa. Selain model pembelajaran faktor lain yang dapat memengaruhi motivasi antara lain cita cita,kondisifisikdanpsikis mahasiswa, kemampuan intelegensimahasiswa, lingkungan, 
dan

pengajar.

${ }^{33}$ Penelitianinitidakmemengaruhinilaimahasiswa.

Teori motivasi Keller menyebutkan hal yang serupa bahwa dengan menggunakan desain dalam proses pembelajaran akan memotivasi siswa baik dalam pembelajaran maupun dalam kinerja praktik. $.{ }^{14},{ }^{18},{ }^{22} \mathrm{Hal}$ tersebut menunjukkan bahwa model pembelajaran terintegrasi yang digunakan dalam proses pembelajaran dapat meningkatkan motivasi siswa dalam praktik klinik kebidanan.

Hasil penelitian menunjukkan terdapat peningkatan kompetensi antara sebelum dan sesudah diberikan model pembelajaran terintegrasi. Model pembelajaran asuhan bayi balita dan anak pra sekolah terintegrasi meningkatkan kompetensi 21,62\%. Hasil tersebut juga didukung dengan hasil uji yang menunjukkan bahwa peningkatan kompetensi mahasiswa tidak berhubungan secara bermakna dengan indeks prestasi mahasiswa $(p>0.05)$. Peningkatan kompetensi mahasiswa dari hasil penelitian tersebut bukan disebabkan oleh indeks prestasi mahasiswa.

Berdasarkan hal diatas model pembelajaran asuhan bayi balita dan anak pra sekolah terintegrasi belum dapat meningkatkan kompetensi mahasiswa secara optimal. Hasil penelitian menunjukkan masih terdapat beberapamahasiswa yang belum mengalami peningkatankompetensiada praktik klinik kebidanan. Praktik klinik kebidanan merupakan suatu proses pembelajaran yang dilakukan oleh program studi kebidanan. ${ }^{19,} 31$ Peserta didik memperolehpengalaman

memberikanasuhanterhadappasien pembelajaranpraktik klinikkebidanan. ${ }^{19}, 31,34,35$ Faktor pengalamantersebut dapat menyebabkan kurang optimalnya peningkatan kompetensimahasiswa.Praktik klinik kebidanan tersebut merupakan pengalaman praktik yang kedua bagi mahasiwa. Kondisi yang dapat menyebabkan kurang maksimalnya peningkatan kompetensi selain hal diatas adalah proses pembelajaran yang diberikanberupapengayaan dalampenelitianini.

Beberapa penelitian menunjukkan bahwa model pembelajaran terintegrasi dapatmembuat peserta didik menjadi lebih baik dalam pengetahuan, sikap, danmotivasi ketika pembelajarandikaitkan dengan bahan pembelajaran yang saling berhubungan. Metode alternatif ini suatu pendekatan yang baik dan bermanfaat bagi peserta didik. ${ }^{14,}$ 15, 17, 30 Hasil penelitian diatas didukung oleh pernyataan oleh Dandannavar (2011) yang menyatakan bahwa pendekatan ideal dalam pembelajaran akan membantu peserta didik mengembangkan pengetahuan, keterampilan, sikap, danmeningkatkan kualitas siswa untukperawatan yang lebih baik terhadap pasien. ${ }^{14,15,17,30}$ Peserta didik dapat memberikan asuhan yang sesuai dengan pengetahuan dan ketrampilan yang didapatkan sebelumnya di kelas untuk dapat diterapkan pada pasien dengan memahami kebutuhan emosional dan psikologis pasien. ${ }^{18,19}$

Hasil penelitian diatas menunjukkan bahwa kepuasan pasien diperoleh dari kualitas pelayanan yang diberikan oleh petugas kesehatan. Petugas kesehatan memberikan kualitas pelayanan sesuai dengan yang diharapkan oleh masyarakat sehingga tercapai kepuasan pasien. Pelayanan yang diberikan oleh petugas kesehatan tentunya dipengaruhi oleh kompetensi petugas. ${ }^{1,4,7}$

\section{Simpulan}

Penerapan

asuhan bayibalitadananakprasekolah terintegrasi dapat menjadi alternatif dalam pembelajaran, karena dapat meningkatkan motivasidan kompetensi mahasiswa dan pada akhirnya dapat menimbulkankepuasan pasien.

\section{Daftar Pustaka}

1. HPEQ. Sistem Penjaminan Mutu Pendidikan Kesehatan: Sebuah Kajian Awal Ditjen Dikti Kemendikbud. 2011.

2. Kemenkes. Kurikulum Inti Pendidikan Diploma III Kebidanan. 2011.

3. Keputusan Menteri Kesehatan Republik Indonesia No 369/MENKES/SK/III/2007 tentang Standar Profesi Bidan. 2007.

4. ICM. International Confederation of Midwives. Essential Competencies for Basic Midwifery Practice. 2010.

5. Dirjen Dikti. Potret Ketersediaan dan Kebutuhan Tenaga Bidan. 2011.

6. Hanafiah N, Suhana C. Konsep Strategi Pembelajaran. Bandung: Refika Aditama; 2010.

7. Shahib MN. Pendidikan Berbasis Kompetensi menuju Invensi. Bandung: Gema Media Pusakatama; Desember 2005.

8. Panitia Penyelenggara Uji Kompetensi Ulang. Panduan Pelaksanaan Uji Kompetensi Ulang Bagi Mahasiswa Program Diploma III Kebidanan, Diploma III Keperawatan Dan Profesi Ners. Dirjen Dikti Kemendikbud 2014.

9. Kemenkes RI. Kualitas Pelayanan Kesehatan Ibu di Indonesia 2012. 2012.

10. Lestari W, Aprianti E. Faktor - Faktor Yang Mempengaruhi Hasil Belajar Mahasiswa Tingkat II 
Prodi D3 Kebidanan STIKes Mercubaktijaya Padang. JSM. 2013;6(1).

11. Irianti B. Pengembangan Model Pembelajaran Asuhan Bayi, Balita dan Anak Prasekolah Terintegrasi pada Pendidikan Kebidanan. IJEMC. Februari 2015;2:3241.

12. Trianto. Model Pembelajaran Terpadu. Jakarta: PT Bumi Aksara; 2014.

13. HPEQ. Draft Standar Kompetensi Bidan Di Indonesia: Ditjen Dikti Kemdikbud; 2011.

14. Dandannavar VS. Curriculum Development for Integrated Teaching (Module) - MBBS Phase I Students. AJEBS. 2011;2(3):478-81.

15. Dandannavar VS. Effect of Integrated Teaching Versus Conventional Lecturing on MBBS Phase I Students. RRST. 2010;2(11):40-8.

16. Kumari K, Vijaya V, Mysorekar, Raja S. Student's Perception About Integrated Teaching In An Undergraduate Medical Curriculum. JCDR. November 2011;5(6):1256-9.

17. Rehman R, Iqbal A, Syed S, Kamran A. Evaluation of Integrated Learning Program of Undergraduate Medical Students. PJP. 2011;7(2):37-41.

18. Gurtoo A, Ranjan P, Sud R, Kumari A. A Study of Acceptability \& Feasibility of Integrating Humanities Based Study Modules in Undergraduate Curriculum. IJMR. Januari 2013;137:197-202.1

19. Pusdiknakes. Panduan Pembelajaran Praktik Klinik Kebidanan Dengan Pendekatan Preceptorship dan Menthorship. 2011.

20. Nagdeo N, Manohar T, Kawthalkar A, Joshi M. Innovative Integrated Teaching for MBBS Undergraduates. SEAJME. 2013;7(2):49-50.

21. Creswell JW. Research Design Pendekatan Kualitatif, Kuantitatif, dan MIxed. Yogyakarta: Pustaka Pelajar; 2013.

22. Adnan, Faisal, Marliyah S. Studi Motivasi Siswa SMP dan Sederajat Di Kota Makassar Pada Mata Pelajaran IPA Biologi. JB. Oktober 2012;13(2):103 -7.

23. Keller J. How to integrate learner motivation planning into lesson planning: The ARCS model approach Florida State University U.S.A. February 2000.
24. Poulsen A, Lam K, Cisneros S, Trust T. ARCS Model of Motivational Design November, 2008.

25. Fadhilah M, Oda Y, Emura S, Yoshioka T, Koizumi $\mathrm{S}$, Onishi H, et al. Patient Satisfaction Questionnaire for Medical Students Performance in a Hospital Outpatient Clinic : A Cross Sectional Study. TJEM. 2011;225:249 - 54 .

26. Klamen DL, Williams RG. The Effect of Medical Education on Students' Patient Satisfaction Ratings. AM. Januari 1997;72(1):57 - 61.

27. Oda Y, Onishi H, Sakemi T, Fujimoto K, Koizumi S. Improvement in Medical Students' Communication and Interpersonal Skills as Evaluated by Patient Satisfaction Questionnaire After Curriculum Reform. JCBN. July 2014;55(1):72 - 7 .

28. Dahlan S. Statistik Untuk Kedokteran dan Kesehatan. Jakarta: Epidemiologi Indonesia; 2014.

29. Chan WP, Hsu CY, Hong CY. Innovative "CaseBased Integrated Teaching" in an Undergraduate Medical Curriculum: Development and Teachers' and Students' Responses. AAM. November 2008;37(1):952-6.

30. Kate MS, J U, Kulkarni, Supe A, Deshmukh. Introducing Integrated Teaching In Undergraduate Medical Curriculum. IJPSR. 2010, 18-22 1(1):18-22.

31. WHO. Modules : 5.Developing a Midwifery Curriculum for Safe Motherhood: Guidelines for Midwifery Education Programmes. 2011.

32. Dimyati, Mudjiono. Belajar dan Pembelajaran. Jakarta: PT Rineka CIpta; 2006.

33. Uno HB. Teori Motivasi dan Pengukurannya. Jakarta: PT Bumi Aksara; 2009.

34. Moore DE, Green JS, Gallis HA. Foundations of Continuing Education Achieving Desired Results and Improved Outcomes: Integrating Planning and Assessment Throughout Learning Activities. JCEITHP. 2009;29(1):1-15.

35. WHO. Modules : 8. Monitoring and Assessment of Continued Competency for Midwifery Practice. 2011. 
Vera Renta S:Peran Penerapan Model Pembelajaran Asuhan Bayi Balita dan Anak Pra Sekolah Terintegrasi terhadap Motivasi dan Kompetensi Mahasiswa serta Kepuasan Pasien Pada Praktik Klinik Kebidanan 